\title{
The Political Economy of the Reconstruction Era's Race Riots
}

\author{
Art Carden ${ }^{\dagger}$ Christopher J. Coyne ${ }^{\ddagger}$
}

\begin{abstract}
This paper analyzes the political economy of the Reconstruction Era's (1865-1877) race riots through the economic logic of rules. The central argument is that the race riots were not an inevitable outcome at the end of the Civil War, but instead occurred because of the absence of effective rules to raise the cost of engaging in violence. We offer a general framework of "rule stickiness" to analyze the process of rule reform. This framework offers insight into the conditions influencing the enforcement costs of formal rules, as well as the likelihood of thirdparty enforcers effectively monitoring and punishing rule breakers. The Memphis race riot of 1866 is provided as a case study to illuminate the explanatory power of the theoretical framework.
\end{abstract}

JEL Codes: D74, B52, N41

Keywords: Reconstruction Era, race riots, rule reform, rule stickiness, Memphis riot of 1866

\footnotetext{
† Corresponding author. Email: cardena@rhodes.edu. Address: Department of Economics and Business, Rhodes College, 2000 North Parkway, Memphis, TN 38112.

‡ Email: ccoyne3@gmu.edu. Address: Department of Economics, George Mason University, MSN 3G4, Fairfax, VA 22030.
} 
The testimony exhibits many individual acts that would disgrace the most ferocious savage, and cause civilization and religion to blush and mourn over the depravity of mankind-such acts as have ever characterized all mobs wherever they have occurred, and will wherever they may occur.-G.S. Shanklin on the Memphis Riot of $1866^{1}$

\section{Introduction}

Over the course of the Reconstruction Era (1865-1877) a series of violent race riots occurred throughout the United States. During the 1860s and 1870s, for example, prominent riots occurred in Memphis, TN (1866), New Orleans, LA (1866), Camilla, GA (1868) Laurens, SC (1870), Meridian, MI (1871), and Colfax, LA (1873), among others. These riots claimed numerous lives, resulted in the destruction of physical property, and hampered the process of post-Civil War reconstruction and reconciliation. Standard explanations for these violent uprisings tend to focus on the role of race relations between blacks and whites. For example, in the case of the Memphis riot of 1866, past scholarship has focused on the presence of black troops in the city (Hardwick 1993), attempts by members of the Irish minority to reassert their white identities (Walker 1998), the novelty of an urban black population (Lovett 1979), and the disfranchisement of former white confederates (Holmes 1958a; Capers 1966). A U.S. Senate report on domestic riots captured the essence of the standard race-driven view when it noted that the "...prolific source of disturbance was the intense feeling toward the colored people [by the whites], many of whom perhaps allowed their freedom to take unnecessary prominence in the presence of their former owners” (U.S. Senate 1903: 108).

The race-driven view of the riots implies that violence was the unavoidable outcome of the preexisting tensions between blacks and whites. However, for economists the inevitability of

${ }^{1}$ G.S. Shanklin, Views of the Minority, (U.S. House 1866: 38). G.S. Shanklin was the conservative member of the committee that investigated the Memphis Riot. More information on the foundations of radical Reconstruction is available in Trefousse (1970). 
conflict, even under situations characterized by high racial tensions, is not so obvious. The economic approach indicates that cooperation and conflict are a function of the existing rules and the enforcement of those rules. Rules find their reason in the need to create parameters on both private and public activity to establish and maintain social harmony and peace (Brennan and Buchanan 1985: ix). Rules, which can be formal - e.g., written laws, legislation - or informal e.g., norms, beliefs - in nature, influence the relative costs and benefits of engaging in certain behaviors (see North 1990, 2005). The economic logic of rules implies that even in the presence of tensions between various individuals and groups - based on race or other factors - conflict is preventable if rules that sufficiently raise the costs of engaging in violent behaviors exist and are effectively enforced. A complete understanding of the Reconstruction Era's race riots, therefore, requires an understanding of the role of rules in failing to prevent violent behaviors motivated by racial tensions.

The purpose of this paper is to analyze the Reconstruction Era's race riots through the economic logic of rules. Our core thesis is that the race riots were not inevitable following the Civil War, but instead occurred owing to the absence of effective rules raising the cost of engaging in violence. This is by no means a denial of the existence of strong racial tensions in the postwar period or an attempt to downplay these tensions in the violent riots during the Reconstruction period. Instead, our purpose is to highlight that these tensions were able to be manifested violently only because rules preventing such behaviors were either absent or not enforced. Simply put, the violent riots occurred because people did not expect to be punished for their actions, which effectively lowered the cost of indulging racist preferences through violence.

Our analysis builds off of Boettke, Coyne and Leeson (2008) who provide a general theory of the stickiness of rules. This theory indicates that because of lower enforcement costs 
formal rules are more likely to stick in the desired manner when they are grounded in existing informal rules. The underlying logic is that where informal rules are at odds with formal rules enforcing the latter will be relatively costly as continued force and coercion by external parties will be necessary in the absence of voluntary compliance. We expand the rule-stickiness framework to focus on how informal rules influence the enforcement of formal rules by thirdparty enforcers. This matters because when there is greater divergence between the formal rules and the informal norms held by citizens, more law-breaking activity will occur. In such instances the importance of external enforcers of formal rules (e.g., police and judges), and thus whether those enforcers' informal beliefs comport with the what formal rules task them with, rises. Applied to third-party enforcers, the rule stickiness framework implies that formal rules that need to be enforced "on the ground" will only be enforced only when the informal norms held by the enforcers do not diverge significantly from the formal rules they are tasked with upholding.

In the context of race riots, formal rules were in place which, in principle, would have protected the basic freedoms and liberties of blacks. However, there was a disjuncture between the formal rules to protect blacks and the informal norms held by both citizens and local white authorities tasked with enforcing those formal rules. The divergence between formal rules and the norms held by citizens created the prospect of violence against blacks and made third-party enforcement crucial. However, the divergence between the formal rules and the informal norms held by third-party enforcers led to a rejection of the content of the formal rules by the very people tasked with enforcing them, lowering the cost of violence against blacks.

Our general theory is applicable to the race riots throughout the Reconstruction Era. In order to illustrate the power of this theory we provide evidence from the Memphis race riot of 1866. As noted, the Memphis riot was one of the prominent instances of violence during the 
Reconstruction Era. It also helped usher in the era of "Radical" Reconstruction. Therefore, studying this event can illustrate how the absence of effective rules can hinder attempts to generate broader institutional changes. Our analysis relies on numerous primary and secondary sources, but our main source is the Congressional Report (U.S. House 1866) on the riot, Memphis Riots and Massacres. The Report provides a range of eyewitness accounts of the riot, as well as on-the-ground explanations for why events unfolded as they did. ${ }^{2}$

Our analysis contributes to two main strands of literature. First, we contribute to the literature which seeks to understand how rules evolve over time (e.g., Aoki 2001; David 1994; Denzau and North 1994; Greif 1994; Greif and Laitin 2004; North 1990, 2005; Boettke, Coyne, Leeson 2008; North, Wallis, and Weingast 2009) by focusing on the conditions under which changes to formal rules are more likely to stick and operate in the desired manner. Our contribution to this literature is to combine insights from the economics of crime (Becker 1968) with the logic of rule stickiness. Second, we contribute to the literature on the Reconstruction Era (Foner 1988, 1990) and to the more narrow literature on the Memphis Riot (Holmes 1958a,b; Burns 1972; Lovett 1979; Waller 1984; Hardwick 1993; Walker 1998; Carriere 2001; Bordelon 2006; Page 2003; Worley 2004; Doyle 2008) by emphasizing the overlooked role of rules in failing to prevent violence given existing racial tensions.

\footnotetext{
${ }^{2}$ Some contemporaries charged that the Report was explicitly political as two of the members of the Investigating Committee were Radical Republicans (Worley 2004). Waller (1984: 234) writes that the Report was "clearly political," and Lovett (1979: 30) writes that the report was explicitly issued to discredit Andrew Johnson by "show[ing] the disloyalty of President Andrew Johnson's home state." However, the Report also contains information on the views of the members of the committee's conservative majority. Even if the Report was motivated by a radical political purpose, it does not necessarily lend itself to radical political conclusions. Further, by supplementing the report with information from additional sources we are able to counteract some of the potential biases. U.S. House (1967) contains a similar investigation of the New Orleans riot of 1866.
} 


\section{Rule Reform and Rule Stickiness}

Economic, political, and social outcomes are a function of formal and informal rules (North 1990, 2005). Together, the "rules of the game" provide incentives that guide behaviors and determine outcomes for better or worse. Rule reforms seek to change existing rules or establish new rules. Successful reform requires making changes to rules that sustain and operate in the desired manner. This, in turn, requires an understanding and appreciation of the relationship between informal and formal rules.

Informal rules refer to the underlying norms, beliefs and attitudes held by people. Hayek (1960, 1988) emphasized that informal institutions were at the core of what he called the "extended order" of human society. Specifically, Hayek (1960: 62) argued that: "We understand one another and get along with one another, are able to act successfully on our plans, because, most of the time, members of our civilization conform to unconscious patterns of conduct...The general observance of these conventions is a necessary condition of orderliness of the world in which we live...” North (2005: 23) places a similar emphasis on informal rules when he writes that “...the beliefs that humans hold determine the choices they make that, in turn, structure the changes in the human landscape.” According to this reasoning, informal rules serve as the foundation for formal rules.

Hayek (1979: 107-8) explicitly notes this connection when he argues that it is the underlying beliefs and dispositions, "which in more fortunate countries have made constitutions work which did not explicitly state all that they presupposed, or which did not even exist in written form.” The broader point is that functioning formal rules are a codification of the underlying beliefs and traditions of a society existing and evolving over for long periods of time. In order for formal rules to operate as desired, they must be supported by certain informal belief 
systems that do not require the designers of formal rules to presuppose every possible future scenario. This logic applies both to the initial establishment of formal rules, as well as to changes to existing formal rules.

The connection between informal and formal rules has important implications for rule enforcement. There are two ways in which formal rules can be enforced—self-enforcement and external enforcement (Becker 1968). While both means can be effective in enforcing rules, they differ in the associated costs. To understand the differences in these costs, first consider a hypothetical scenario of 'perfect alignment' where informal rules align perfectly with the formal rules. In such an instance, the enforcement costs of formal rules will be zero since people voluntarily will follow what the formal rules dictate given that they map perfectly to their underlying beliefs and attitudes. Self enforcement through informal monitoring will raise the relative price of deviations from the formal rules, making external enforcement less necessary.

In contrast, consider the other extreme, hypothetical scenario of 'perfect opposition', wherein informal rules are completely at odds with existing formal rules. In such a case, enforcing formal rules will be relatively costly as third party monitoring and enforcement will be necessary to raise the cost of deviations from the formal rules since internal enforcement will be largely ineffective. ${ }^{3}$ The relatively high enforcement cost will manifest itself both in terms of the resources necessary to maintain order, as well as the level of coercion required to ensure that people, whose underlying beliefs and attitudes are at odds with the formal rules, acquiesce to the dictates specified by the formal rules.

Most societies do not neatly map into one of these extreme categories, but instead operate based on some mix of informal beliefs and third-party, external enforcement to ensure

${ }^{3}$ The provision of criminal justice is typically viewed as falling under the purview of government. However, research indicates that in some cases criminal justice can emerge endogenously absent state provision (see Benson 1990; 1998; Leeson 2006; 2007a,b,c; 2008; 2009a). 
compliance with formal rules. Nonetheless, considering these two conceptual categories highlights the relative costs of enforcement depending on whether a society is closer to the “perfect alignment” or “perfect opposition” end of the rule-enforcement spectrum.

From the perspective of rule reform the logic of rule stickiness matters because reform is not simply a matter of “outsiders" designing what they perceive to be the appropriate formal rules. In this context, “outsiders” refers not to some notion of physical distance (e.g., those physically outside the society), but rather to knowledge distance (e.g., those outside of the relevant knowledge context). For example, reform efforts may involve those at the national level working to design and implement rule reforms at the local level. Even though the national leaders are citizens of the society where rule reforms are occurring, they may still be outsiders with respect to possessing the local knowledge that is necessary to implement effective rule reforms. Boettke, Coyne, and Leeson (2008) emphasize that the relevant issue is the knowledge distance between the reform planner and the context in which the reform is being implemented. This is important because when rule enforcers lack the necessary context-specific knowledge (i.e., a significant knowledge distance exists) of informal rules, reforms to formal rules will be less likely to stick due to the disconnect with underlying beliefs. Absent the appropriate beliefs held by citizens to support formal rules, continued third-party coercion will be necessary in the absence of voluntary compliance.

The logic of rule stickiness also has important implications for our understanding of third-party enforcement. When the informal rules held by citizens diverge from formal rules, the importance of third-party enforcers of formal rules, and thus whether those enforcers' views align with the content and spirit of formal rules, rises. Third-party rule enforcers cannot simply be treated as exogenous, benevolent actors because their effectiveness as enforcers is influenced 
by the informal norms they follow in deciding whether to uphold formal laws. If the informal norms held by enforcers deviate significantly from the formal rules they are tasked with enforcing, they will fail to uphold the formal rules which are already being ignored by citizens. The implications as they relate to the effectiveness of external enforcers of formal rules can be understood as follows.

Where the informal beliefs and attitudes held by third-party enforcers do not align with the formal rules, the authorities will fail to enforce the formal rules, rendering them ineffective. ${ }^{4}$ In this case citizens will fail to follow the rules given the divergence between informal and formal rules, and enforcers will fail in their role of ensuring compliance. When third-party enforcers fail to respect and uphold the formal rules, the cost to citizens of violating those rules falls, all else constant. To understand why this is the case, consider that the consequences of deviations from the formal rules is a function of the probability of being caught and the associated punishment if caught (Becker 1968). When given the authority, third-party enforcers possess the power to monitor and punish deviations from the dictates of formal rules. If the authorities tasked with enforcing formal rules refuse to do so, then the price of deviations falls as people will realize that the probability of being caught and punished for violations is low.

One can find numerous present-day examples where authorities refuse to enforce formal laws due to a divergence from the informal norms held by enforcers. For example, following the collapse of the U.S. housing market, numerous local sheriffs' offices refused to enforce foreclosure eviction laws in their jurisdictions because they considered them unfair to homeowners and renters (see, for example, Babwin 2010). Similarly, local sheriffs have refused

\footnotetext{
${ }^{4}$ Of course another layer of enforcement could be established to constrain the rule-enforcers who would otherwise fail to enforce the formal rules, but this just pushes the problem up another level. This is the classic "Quis custodiet ipsos custodes?" ("who will guard the guards themselves?") problem. At some level of enforcement the informal rules must align with the formal rules in order for the latter to be enforced at all.
} 
to enforce state immigration laws that they view as unjust to illegal immigrants (see, for example, Friedman 2010). As these examples illustrate, when the informal norms held by the third-party enforcers of formal rules are at odds with the rules they are tasked with upholding, then formal rules will be ineffective absent additional layers of external enforcement.

\section{The Memphis Riot of $\mathbf{1 8 6 6}$}

\subsection{Background and Context}

The pre- and post-Civil War situation in Memphis illustrates the explanatory power of the rule reform and rule stickiness framework. To understand how, a broader understanding of the situation in Tennessee is necessary to establish the existing norms, rules, and vested interests, as well as efforts to engage in formal rule reform. This context will then allow us to apply the logic of rule stickiness discussed in the previous section.

We begin in January 1861. After a number of failed attempts to adopt a resolution of secession in January and February, the Tennessee legislature entered into a military league agreement with the Confederacy in May. A month later, another secession referendum narrowly passed, making Tennessee the last state to secede from the Union. Just a few days after the referendum passed, the Tennessee legislature approved the drafting of free black males into the Confederate army. In February of 1862, a series of battles resulted in the Union securing key parts of Tennessee. In late February, General Ulysses S. Grant and the Union forces secured western Tennessee and declared martial law. Just a few days later, Union forces took Nashville, the first confederate state capital to fall to the Union. This marked the official beginning of the Union’s occupation of Tennessee, with President Lincoln naming Andrew Johnson, who would 
later become Lincoln's Vice President and subsequently President of the United States, as the military governor charged with overseeing the occupying forces.

With the capture of Memphis on June 6, 1862, Union forces secured control of the Memphis port which allowed them to easily access the Mississippi River to transport supplies. Although Memphis had fallen to the Union, the city also served as a central hub for black market contraband to Confederate troops. To offer some insight into the extent of the contraband market, consider that in 1864 the Union Congressional Committee on the Conduct of the War estimated “that between $\$ 20,000,000$ and $\$ 30,000,000$ worth of supplies have passed through this city into the hand of the Confederacy" (quoted in Cunningham 1993: 137). The magnitude of the contraband trade led one Union general to conclude that "Memphis has been of more value to the Southern Confederacy since it fell into Federal hands” (quoted in Cunningham 1993: 137). This is important because, although the city was technically under Union hegemony, the thriving black market indicates that Union forces had far from complete control of the city and that informal norms supporting the goals of the Confederate States of America still persisted. These norms were largely at odds with what reforms to formal rules sought to accomplish in terms of protecting the basic rights of blacks.

In addition to the strong, and continued, confederate presence, changes to Memphis’s population were another factor contributing to rising racial tensions that would eventually motivate the violent riot years later. The city became a focal point of refuge for runaway slaves seeking protection from their owners. Additionally, Fort Pickering was constructed in Memphis in June 1862, becoming a training depot and post for several regiments of the United States Colored Troops (USCT), which were part of the Union forces. Consider that from 1860 to 1865 the number of blacks in Memphis increased from 3,882 to over 20,000 (Page 2002: 79; Fordney 
2008: 123). In addition to an increase in the black population, there also was an influx of white Irish immigrants. This influx was a response to the increased demand for physical labor resulting from the construction of four major railways in the Memphis area (Walker 1998: 36). ${ }^{5}$ The white Irish population of Memphis increased from 876 to 5,242 between 1850 and 1860 (Walker 1998: 36). People of Irish extraction comprised only 9.9\% of the population in 1850, but $23.2 \%$ in 1860 (Walker 1998: 36; Carriere 2001; Bordelon 2006). These changes to Memphis's demographics contributed to economic tensions by creating competition for jobs, which reinforced further existing racial and social tensions (Burns 1972: 21-22). The freedmen who couldn’t find jobs were viewed by many whites as a burden on social institutions. Foner (1988: 262) captures these tensions when he writes, "It is difficult to say which proved more threatening to local whitesthe large number of impoverished rural freedman...or the considerable group that managed to achieve modest economic success.”

The change in the city's demographics also had an important impact on local politics. During Union occupation, city politics fell under the control of the Irish minority. This occurred because confederates, and confederate sympathizers, were disfranchised and barred from public office, while blacks had no political rights. The result was a power vacuum in city politics that was filled by the Irish immigrants. This allowed those who secured political positions to use their power to provide political favors. For example, Mayor John Park, a Nova Scotian of Irish origin who closely identified with Irish laborers, used municipal offices (e.g., the police force and the fire department) to dispense political patronage to select individuals. Similar outcomes emerged in other Southern cities, as the Irish minority took advantage of the power vacuum left by the war

\footnotetext{
${ }^{5}$ The demand for non-slave labor increased due to a law passed in Alabama in the early 1850s holding those that contracted with slave owners to be fully liable for any damages to the slave occurring in tasks which were "contrary to the ordinary pursuits for which slaves are used" (quoted in Walker 1998: 36). Railroad construction was notoriously dangerous with a high risk of bodily injury and given the precedent established by the Alabama law, railroad companies substituted white labor for slave labor.
} 
to secure municipal offices like the police. Gleeson (2000: 44) notes that in "Charleston and New Orleans in particular, they [the Irish] dominated the antebellum police forces.” In Memphis, and elsewhere, the ultimate outcome of this dominance was the emergence of a vested interest which faced the following tension: municipal officers were tasked with upholding and enforcing the rights of freed blacks, but they also had an incentive to ensure that freed blacks would not threaten their positions of political power. These incentives encouraged behaviors by Irish officeholders that undermined their effectiveness as rule enforcers.

These tensions were exacerbated further by the work of the Freedman's Bureau, which was established by the U.S. Congress in March 1865 to assist with the transition of former slaves into free men. The activities of the Bureau, which included building schools and hospitals for blacks, as well as providing employment assistance, were resented by whites, especially lowerincome whites, throughout the city who saw the blacks as receiving unfair advantages which threatened their standard of living (see Fordney 2008: 124). So while reforms to formal rules would require the equal treatment of freed blacks, the reality was that many whites in Memphis viewed them not only as inferior, but as receiving special, and often unfair, treatment and advantages. The Memphis Argus captured the widespread views of many whites in Memphis when it wrote the following regarding freed blacks: "Would to God they were back in Africa, or some other seaport town...anywhere but here" (quoted in Foner 1988: 262). It was these types of beliefs that underpinned the divergence between the informal norms governing everyday behaviors and the formal rules intended to grant protection of equality to blacks.

In January 1863, President Lincoln issued the Emancipation Proclamation, which freed slaves in those states under Confederate control. Tennessee was excluded, despite the fact that slavery still existed in the state, given that it was already under Union control. However, “(b)y 
the end of 1863, [Governor Andrew] Johnson had declared for abolition in Tennessee,” and in April 1865 voters adopted a new state constitution which included an anti-slavery amendment (Foner 1988: 44). Just days after the adoption of the new constitution, Tennessee's General Assembly ratified, as a condition for reentry into the Union, the $13^{\text {th }}$ Amendment to the U.S. Constitution which legally abolished slavery and involuntary servitude. Despite these formal laws protecting the basic rights and freedoms of blacks, a year later, on May 1, 1866, the Memphis riot occurred. The specific events surrounding the riot can be understood as follows.

On May $1^{\text {st }}$, a group of approximately one hundred blacks gathered on South Street in Memphis. A large portion of the crowd consisted of black soldiers who had recently been discharged from their duties at Fort Pickering. In the opinion of the riot's investigators, their "riotous and disorderly" behavior "fully justified the interposition of the civil authorities" who, when they arrived, had found the soldiers “cheering for 'Abe Lincoln”” (U.S. House 1866: 7). One of the officers replied to their cheers by saying "Your old father, Abe Lincoln, is dead and damned” (U.S. House 1866: 7).

In a separate, but simultaneous event, there was a minor collision between two hack drivers - one black, one white. The black driver attempted to disappear into the crowd of recently discharged black soldiers (Carriere 2001; Foner 1990: 117). In response to this event, the white police arrested two men "in an orderly manner" (U.S. House 1866: 7). However, a black man who had had been arrested violently the previous week near Fort Pickering "discovered among the policemen making the arrests the very man who had arrested him" (U.S. House 1866: 7). Shouts of "Club them! Shoot them!," were directed at the white police from the black crowd and some of the black soldiers, who had been allowed to keep their side arms even after being discharged, fired them into the air (U.S. House 1866: 7; Ryan 1977: 246-247; Lovett 
1979: 20). The police, thinking they were being fired upon, turned and started shooting at the soldiers. More violence quickly ensued due to "a promiscuous running fight between the police and colored soldiers" (U.S. House 1866: 7). The fighting stopped by nightfall and the soldiers returned to Fort Pickering. The fort's commanders disarmed the soldiers and confined them to the base, which meant that they did not play a role in the subsequent events associated with the riot.

Violence continued the next day (May $2^{\text {nd }}$ ), spurred by a variety of factors. Rumors spread throughout the city that blacks were engaged in armed rebellion, providing fuel for a violent response by whites. In his minority report on the riot, G.S. Shanklin reports that a group of whites on horseback had approached Fort Pickering, carrying a black flag. ${ }^{6}$ Witness Tony Cherry testified that the black troops interpreted the whites' black flag as a threat that they would be granted no quarter (U.S. House 1866: 184). In response, the black soldiers shot the white flagbearer. Additionally, a large group of whites, which included police officers and fire fighters, gathered in the area where the violence had broken out the day before (U.S. House 1866: 39-40). Finding no blacks in that specific area, the mob entered freedmen's settlements, engaging in violent act against black citizens as well as the missionaries working in the settlements. Indeed, it was noted that 'there was a disposition on the part of 'numbers of the mob' to interfere with the white people engaged in educating and Christianizing the colored people” (U.S. House 1866:28). Violent outbreaks continued throughout the city until General George Stoneman, who was commanding officer of the federal forces in Tennessee, restored order by mobilizing additional troops and declaring martial law.

\footnotetext{
${ }^{6}$ The Memphis Argus (1866b) also reported that some blacks had waved a black flag at one point, but the Argus was one of the papers condemned by the investigators and others for its role in provoking the violence. For an economic analysis of flags as a mechanism for signaling agent type, see Leeson (2009b: 82-106).
} 
There is no doubt that existing racial tensions fueled the violence associated with the riot. However, the interesting question is how violence erupted after the Union had won the war and after formal rules establishing the freedom of blacks had been adopted. Formal rules clearly were established giving blacks basic freedoms and protections to them, meaning that, in principle, violence should have been prevented if enforcement of the rules was effective. There clearly was a gap between these formal and informal rules governing the behavior of many white citizens who refused to accept blacks as equal. Nonetheless, third-party enforcers - local police and federal troops - were tasked with enforcing the formal laws. Even in the presence of racial tensions conflict was in principle avoidable if the third-party enforcers had effectively performed the task assigned to them. The relevant question is: Why, despite formal rules protecting blacks and the presence of third-party enforcers did violence occur in Memphis? The answer lies in the fact that the norms held by, and incentives facing, third-party enforcers diverged from the spirit and content of the formal rules. The need for external enforcement was predicated on the fact that many white citizens rejected the formal rules protecting blacks. However, the enforcers also rejected the formal rules, meaning that, blacks had little protection against violent criminal acts committed by citizens and the very people tasked with enforcing the formal rules.

\subsection{Why the Riot?}

The formal military rule of Tennessee ended on July 3, 1865, when Major-General John E. Smith, then commanding the Federal troops, revoked the orders that had dissolved the local government. Federal troops nevertheless remained in Tennessee, including Memphis, under the

control of General George Stoneman. In Memphis, power was officially turned over to the municipal government and the predominantly white Irish police force, which was tasked with 
enforcing formal rules, including those that protected blacks. This was problematic from the standpoint that many in the police force did not support or respect the formal rules they were tasked with enforcing for the reasons discussed in the previous subsection. With a monopoly on force and the incentive to stifle threats to their positions of power, the white police could undermine the very laws they were responsible for upholding, leaving blacks with little formal recourse. This resulted in the weak enforcement of laws, which reduced the price of both citizens and enforcers engaging in violence against blacks.

The existing tensions between the white police and black soldiers in Memphis were illustrated by Freedmen’s Bureau Superintendent Benjamin Runkle (1866: 276) who identified the "feud between these [black] soldiers and their ancient enemies, the police" as the underlying cause of the riot. Similarly, according to the testimony of James H. Swan, there was considerable conflict over legitimacy and rule between the discharged black soldiers and the Irish police officers: "There has seemed be a competition which should excel in authority. The policemen did not want to give up to them, and the colored guards did not want to give up to the police” (U.S. House 1866: 178). As this testimony indicates, there was a fundamental tension in that those tasked with enforcing formal rules also had an incentive to undermine those rules in order to maintain their vested interests.

The conduct of some of the city's white police demonstrates the general lack of respect for the basic rights that were supposedly at the core of the formal rule they were responsible for enforcing. According to Robert Church's sworn affidavit in the wake of the massacre,

On the 2 of May 1866 a number of persons jumped on a colored man near my place and abused him very badly. He ran into the Saloon-they followed him and said 'close the door' but in the place of closing the door they commenced shooting-one shot took effect in my arm and one in my neck-they then drank all the whiskey they wanted and took a lot 
of cigars, I don't know how many, also some money. Two of the Policemen were named Dave Roach and Shelby (Assistant Commissioner for the State of Tennessee 1866-1868).

Church further implicated Roach's riotous behavior by claiming that he had failed to prevent "Policeman No. 144" from pistol-whipping a black man (Assistant Commissioner for the State of Tennessee 1866-1868).

Henry Bond testified that on May 1 he witnessed:

"about a hundred men, and two policemen had the colored soldier, each by one arm. The constable, Bill O’Hern, came up, riding a pony. 'Gentlemen,' said he, 'let me shoot that fellow,' and he out with his pistol and shot him in the neck. Then the colored man broke and came running through the yard, trying to save himself, but a white man pushed him back, and he ran round the house to the corner of Mulberry street and Brown's avenue, and there they finished him" (U.S. House 1866: 199).

As further evidence that the white police in Memphis were not only ineffective in the monitoring and enforcement of formal rules, but also that some of them were active participants in criminal behavior, consider the case of Albert Harris, a black shoemaker.

Early in the evening about eight men came to his house, two or three of them being policemen, under the pretext of searching for arms. They ransacked his house, broke open his trunks, and robbed him of $\$ 350$ of his own money, the fruits of his hard earnings, of $\$ 50$ placed in his care, and $\$ 10$ belonging to another man. His wife seeing policemen in this gang of robbers, tried to get them to interfere, but they drew their pistols, and pointed them at the side of her head. When they were going off, Albert begged them not to carry away his money; it was all he had, and he had 'worked hard for it.' They derisively told him to go to the Freedmen's Bureau in the morning and he would get it (US House 1866: $10)$.

Other examples of the police undermining the very rules they were tasked with upholding are evident in the reported cases of sexual violence. For example, Frances Thompson testified that she was raped by seven Irishmen, who had appeared at her house demanding food. After she fed them, they raped both her and Lucy Smith, a sixteen-year-old who was living with 
Thompson. These men then robbed them, saying that "they intended to 'burn up the last God damned nigger”" (U.S. House 1866: 197). Lucy Smith testified that after they had finished their business they took "(w)hat was left of the sugar, and coffee, and ham [and] threw [it] in the bayou” (U.S. House 1866: 197). In total, five black women were raped during the riot, and their assailants went unpunished. In some cases the victims reported that the police were actively involved in committing the crime. For example, in response to the question "Did you know any of the men?," Lucy Smith testified that "There were two policemen with the men; I saw their stars” (U.S. House 1866: 197). ${ }^{7}$

Several Memphis city officials, who held positions of power, which included overseeing the police, actively were involved in encouraging and participating in the violence against blacks. For example, the Memphis Public Ledger wrote that "Mayor Park was on the field cheering the people [white rioters] and doing so nobly.” Judge of the Recorder's Court John C. Creighton also was singled out as "(t)he ringleader of this work of murder, incendiarism, and butchery” (U.S. House 1866: 23). Finally, attorney general of the criminal court William Wallace also led part of a white posse and was responsible for arming a number of them after procuring arms at Folsom \& Co.’s gun store (Worley 2004; U.S. House 1866: 246-247, 314; Walker 1998: 41).

The ineffectiveness of the police and city officials in enforcing formal rules reduced the price of white citizens engaging in violent criminal behavior against blacks because the

\footnotetext{
${ }^{7}$ There is debate over the number of police and firefighters involved in the riot. Sixty-eight rioters were identified by name in the Congressional Report. Of these, Waller (1984: 237) argues that 16 were police officers and seven were firefighters. Examining payroll records and other sources, Worley (2004: 54-55) could confirm that only two of those named as rioters "were actually working as firemen at the time of the riots" and that only seven of the named rioters "were definitely working as police officers at the time." No matter the actual number, the fact that current and former police officers played prominent roles in the riot suggests a relatively low probability of punishment for other rioters, supporting our point regarding the reduced cost of engaging in criminal behaviors.

${ }^{8}$ There also were reports that Park was drunk and unfit for duty as the mayor of the city. For example, the report on the riot noted that Park was "unequal to the occasion, either from sympathy with the mob, or on account of drunkenness during the whole time” (U.S. House 1866: 23).
} 
probabilities of detection and punishment were extremely low. Further, the fact that some of the rule enforcers were active participants in the violence further undermined the formal rules, as others saw the rules as inapplicable and irrelevant.

In principle, the federal forces stationed in Memphis could have filled the gap of monitoring and enforcement by exerting authority over the municipality's third-party enforcers. In other words, federal forces could have served as a meta-enforcer to ensure that both local law enforcement and citizens complied with formal rules. Indeed, the riot eventually ended after General Stoneman intervened with federal forces and declared martial law in Memphis. Given this, why didn’t federal forces intervene earlier?

A central part of the answer is that there was a lack of clarity over the role of federal troops following the official end of the federal military rule in July 1865. This lack of clarity was evident in Stoneman's initial response to County Sheriff T.M. Winters, who appealed to General Stoneman for troops after the initial outbreak of violence on May $1^{\text {st }}$. Stoneman refused to provide troops on the grounds that the people of Memphis had "petitioned the government to have the troops removed” (U.S. House 1866: 80). As an alternative, Stoneman advised Winters to assemble a local posse to put down the violence and restore order. This posse, however, ended up contributing to the violence and, in hindsight, Stoneman's refusal “...to declare martial law until May 3 needlessly exposed Memphis' black community to the naked fury of armed white mobs” (Ryan 1977: 244). At least part of Stoneman's indecision was due to the blurry boundaries between federal and local law enforcers.

In addition to the ineffectiveness of law enforcement, mechanisms for determining culpability and determining punishments were also lacking in Memphis. Indeed, Tennessee’s court system was adversely affected by the war and Reconstruction. Disenfranchisement 
restricted the pool of potential jurors and, in the eyes of some witnesses, limited the courts' ability to administer justice in a fair and efficient manner. This was evident from the testimony of Judge William Hunter, a northerner who had come to Memphis in 1862 as a judge in the criminal court of Memphis six months before the riot. While he saw none of the violence in person, Hunter testified that the chances of a white person being convicted for crimes against blacks was "remote" because "(t)here is another class, from whom most of our juries are made up, that would be utterly incapable of doing justice, and enforcing the law with anything like impartiality” (U.S. House 1866: 75). He blamed this, at least partially, on the disfranchisement law when he noted that "( $\mathrm{t}$ )he qualified voters are a worse element than those disfranchised under a strict application of the franchise law" (U.S. House 1866: 75). ${ }^{9}$

Similarly, Benjamin Runkle testified to the dysfunction of the court system when he stated that it "seemed impossible for me to get justice done; there was an instance, just before I came here of a man who, seemingly for mere amusement, killed three [blacks]; he was let out on \$2,000 bail, and nothing has been done with him since” (U.S. House 1866: 277). Lovett (1979: 29-30) reports that after the riot, General Clinton B. Fisk (Assistant Commissioner for the Tennessee Freedmen's Bureau) thought civil trials would not work to punish the rioters because blacks could not testify in Tennessee courts. Fisk was refused his request to have rioters tried in Freedmen's Bureau courts, and Stoneman did not think the rioters could be punished by military tribunals (Lovett 1979: 29-30).

The ineffectiveness of courts was evident by the lack of accountability following the riot. In a response to an inquiry from General Stoneman asking whether the local authorities had acted to compensate the victims of the riot, Mayor John Park framed the violence as a product of "negro rioters" and said "The city authorities have taken no steps or measures in the premises...I

\footnotetext{
${ }^{9}$ See Walker (1998: 37-38) for a discussion of the disenfranchisement law.
} 
take it for granted that no action will be had. I am not advised that a claim 'for losses sustained and expenses incurred by the riotous proceedings of the people of Memphis' had been or would be recognized by any tribunal of competent jurisdiction as a constituting a meritorious claim against the civil authorities" (U.S. House 1866: 54-55). Perhaps the best indication of the breakdown in criminal justice was that of those involved in the riot, no whites were prosecuted for riotous depredations (U.S. House 1866:165, 174, 191, 296; Bergeron 1992: 513; Holmes 1958b: 69-70). James Speed, the U.S. Attorney General at the time, determined that any judicial action associated with the riot fell to the state (Ryan 1977: 257, fn 94). However, those at the state and local levels refused to pursue criminal proceedings against those responsible.

The Memphis Riot of 1866 occurred because of a complete breakdown in the criminal justice system. A key aspect of criminal deterrence is the expectation of external monitoring, rule enforcement, and punishment for rule violations. When third-party enforcers not only refuse to enforce rules, but actively break them, the price of criminal behavior is reduced for others who view formal rules as irrelevant. Similarly, when courts are dysfunctional in terms of punishing rule violators effectively, it reduces the price of engaging in criminal activity by lowering the expected punishment. In Memphis, the absence of effective criminal justice on all of these margins allowed for violence despite the presence of formal rules which, in principle, could have prevented such an outcome if properly upheld and enforced

While we focused on Memphis, we should note that our general framework is applicable to a variety of Reconstruction era riots. Although in each instance the particular circumstances of the riots varied, the logic of rule stickiness and the ineffectiveness of third-party rule enforcers played a central role. For example, in discussing the New Orleans riot of 1866, Foner (2005: 118-9) notes that "a white mob led by local police descended on a march of several hundred 
black supporters of the [Constitutional] convention. In the melee that followed, some thirty-eight persons were killed and 146 wounded, mostly blacks." He concludes that "The role of city police in contributing to the violence rather than restoring order suggested that the southern governments...were unwilling or unable to protect the basic rights of citizens” (Foner 2005: 119). As in Memphis, in New Orleans the norms and incentives shaping the behavior of thirdparty rule enforcers were at odds with the formal rules they were tasked with enforcing. ${ }^{10}$ The result was a rejection of the formal rules lowering the price of violent criminal behavior against blacks.

\section{Conclusion}

Our analysis has three related implications illustrated by the Memphis Riot of 1866. First, the reform of formal rules requires an appreciation of the existing informal rules as they relate to enforcement costs. Where formal and informal rules align, the cost of enforcing formal rules will be relatively low because the voluntary actions of people based on informal rules will tend to align with what formal rules dictate. In contrast, where there is a disjuncture between formal and informal rules the cost of enforcing formal rules will be relatively high. In such instances, a third-party enforcer will be necessary to enforce compliance between what formal rules state and what custom dictates.

Second, it cannot be assumed that third-party rule enforcers are exogenous to the rules they are tasked with upholding. The behavior of rule enforcers is influenced by an array of informal and formal rules just like the citizens over which they have authority. Rule enforcers have the power to enforce rules, which means that they also have the ability to ignore or

\footnotetext{
${ }^{10}$ For more on the New Orleans Riot see Vandal (1983) and Foner (1988, 1990, 2005).
} 
undermine those rules. If the norms and incentives governing the behavior of rule enforcers are at odds with the formal rules they are responsible for enforcing, then formal rules will fail to be upheld effectively. More generally, the failure of third-party rule enforcers to punish deviations from the formal rules lowers the price of engaging in criminal activity.

Finally, the potential for dysfunctional criminal justice in the wake of rule reform has implications for the way that we think about public goods provision more broadly. Public economics often treats the existence of public characteristics as prima facie evidence justifying government provision (or subsidization) of that good. The Memphis riot suggests that this reasoning is not, by itself, sufficient for government provision of goods. Governments are responsive to political signals and in a situation such as in 1866 Memphis, where many held pathological racial preferences, we can expect government agents to respond to political incentives not by correcting an externality, but either by standing idly by or by actively using their power to harm and repress certain groups. When it is relatively cheap to indulge certain preferences, due to the absence of effective rule constraining government, granting political elites expansive powers can have disastrous consequences. 


\section{Acknowledgements}

This research was supported by a generous grant from the Mike Curb Institute for Music at Rhodes College. Carden acknowledges the financial support of the American Institute for Economic Research, where he was a Visiting Research Fellow during summer of 2009 and 2011, and a CAP-Mellon Study Leave at Rhodes College during Spring 2010. Tyler Ponder provided research assistance during early explorations of these themes in summer 2008, and Julie Doub, Rachel Smith, Rachel Webb and Sameer Warraich assisted with the research at various stages. Numerous people proofread different drafts, including Julia Clapper, George Ryan Connor, and Linda Gibson. Timothy Huebner graciously directed us to student research on the Memphis Riot, and Charles McKinney provided valuable discussions. William Shughart, Peter T. Leeson, Stephanie Moussalli, Luigi Marco Bassani, and several anonymous referees offered very useful and valuable comments. We also acknowledge the assistance and support of the Memphis and Shelby County Room at the Benjamin C. Hooks Central Library in Memphis. Participants in a seminar at Indiana University's Workshop in Political Theory and Policy Analysis and at the 2009 meetings of the Tennessee Conference of Historians, the 2009 Southern Economic Association, the 2010 Association of Private Enterprise Education meetings, the 2010 Istituto Bruno Leoni Mises Seminar, and the 2010 Missouri Valley Economic Association provided valuable comments and suggestions. 


\section{References}

Aoki, M. (2001). Toward a comparative institutional analysis, Cambridge: MIT Press.

Assistant Commissioner for the State of Tennessee Bureau of Refugees, Freedmen, and Abandoned Lands, 1865-1869. 1866-1868. Reports of outrages, riots, and murders, Jan. 15, 1866-Aug. 12, 1868, National Archives Microfilm Publication M999, roll 34. Search: http://www.freedmensbureau.com/tennessee/affidavits. On file in the Memphis Room at the Memphis Public Library, retrieved on January 5, 2007.

Babwin, D. (2010). Tom Dart halts foreclosure evictions, October 19, Available online: http://www.huffingtonpost.com/2010/10/19/tom-dart-halts-foreclosur_n_768257.html

Becker, G. (1968). Crime and punishment: an economic approach. The Journal of Political Economy, 76(2), 169-217.

Bergeron, P.H. ed. (1992). James B. Bingham to Andrew Johnson, 5/17/1866, In The papers of Andrew Johnson: Volume 10, February-July 1866. Knoxville: University of Tennessee Press, pp. 513.

Benson, B. (1990). The enterprise of law: justice without the state, San Francisco: Pacific Research Institute for Public Policy.

. (1998). To serve and protect: privatization and community in criminal justice, New York: New York University Press.

Berkeley, K.C. (1980). Like a plague of locust: Immigration and social change in Memphis, Tennessee 1850-1880. PhD Dissertation: University of California, Los Angeles.

Boettke, P.J., Coyne, C.J. and Leeson, P.T. (2008). Institutional stickiness and the new development economics. American Journal of Economics and Sociology, 67(2), 331-358.

Bordelon, J. (2006). 'Rebels to the core': Memphians under William T. Sherman. Rhodes' Journal of Regional Studies, 3, 7-36.

Burns, V.L. (1972). The Memphis Race Riot of 1866. Unpublished MA Thesis, Memphis State University.

Capers, G.M. (1966). Biography of a river town: Memphis-it's heroic age. New Orleans: Tulane University Press.

Carriere, M. (2001). An irresponsible press: Memphis newspapers and the 1866 riot. Tennessee Historical Quarterly, 60(1):2-15.

Cunningham, H.H. (1993). Doctors in gray: the Confederate medical service. Louisiana: Louisiana State University Press. 
David, P. (1994). Why are institutions the 'carriers of history': path-dependence and the evolution of conventions, organizations and institutions. Structural Change and Economic Dynamics, 5(2), 205-220.

Denzau, A. and North, D.C. (1994). Shared mental models: Ideologies and institutions. Kyklos, 47(1), 3-31.

Doyle, J.P. (2008). The worst behaved city in the union: The impact of the Memphis Riots on reconstruction politics. Unpublished B.A. Honors Thesis, Rhodes College.

Foner, E. (1988). Reconstruction: America's unfinished revolution. New York: Harper and Row. . (1990). A short history of reconstruction. New York: Harper and Row. (2005). Forever free: the story of emancipation \& reconstruction. New York: Vintage Books.

Fordney, B.F. (2008). George Stoneman: a biography of the union general. North Carolina: McFarland \& Company, Inc.

Friedman, E. (2010). Arizona sheriff says he will refuse to enforce immigration law, April 27, Available online: http://abcnews.go.com/WN/protestors-arizona-immigration-bill-urgeboycott-state/story?id=10487582\#.Trrqk7Ks_Wc

Gleeson, D.T. (2000). The Irish in the south, 1815-1877. Chapel Hill: University of North Carolina Press.

Greif, A. (1994). Cultural beliefs and the organization of society: Historical and theoretical reflection on collectivist and individualist societies. Journal of Political Economy, 102(5), 912-50.

Greif, A. and Laitin, D.D. (2004). A theory of endogenous institutional change. American Political Science Review, 98(4), 633-652.

Hardwick, K. (1993). 'Your old father Abe Lincoln is dead and damned': Black soldiers and the Memphis Race Riot of 1866. Journal of Social History, 27(1), 109-128.

Hayek, F.A. (1960). The constitution of liberty. Chicago: The University of Chicago Press. . (1979). Law, legislation, and liberty, Volume III: The political order of a free people. Chicago, IL: The University of Chicago Press. . (1988). The fatal conceit: The errors of socialism. Chicago: The University of Chicago Press. 
Holmes, J.D.L. (1958a). The underlying causes of the Memphis Race Riot of 1866. Tennessee Historical Quarterly, 17(1), 195-221.

. (1958b). The effects of the Memphis Race Riot of 1866. West Tennessee Historical Society Papers, 12, 58-79.

Leeson, P.T. (2006). Cooperation and conflict: evidence on self-enforcing arrangements and heterogeneous groups. American Journal of Economics and Sociology, 65(4), 891-907.

. (2007a). Trading with bandits. Journal of Law and Economics, 50(2), 303-321.

. (2007b). Efficient anarchy. Public Choice, 130(1-2), 41-53.

. (2007c). An-arrgh-chy: The law and economics of pirate organization. Journal of Political Economy, 115(6), 1049-1094.

. (2008). Social distance and self-enforcing exchange. Journal of Legal Studies, 37(1), 161-188.

. (2009a). The laws of lawlessness. Journal of Legal Studies, 38(2), 471-503.

. (2009b). The invisible hook: the hidden economics of pirates. Princeton: Princeton University Press.

Lovett, B.L. (1979). Memphis Riots: white reaction to blacks in Memphis, May 1865-July 1866. Tennessee Historical Quarterly, Spring, 9-33.

Macon Daily Telegraph. (1866). The Negro Riot at Memphis [Special Dispatch to the Louisville Courier]. May 5, 1866, p. 2.

Memphis Daily Argus. (1866a), MILITARY VS. CIVIL: Direct Conflict between the Civil and Military Authorities of Kentucky. May 1, 1866, p. 1. . (1866b) “THE RIOTS.” May 3, 1866, p. 3.

Memphis Public Ledger. (1866). “SECOND DAY OF THE FIGHT.” May 2, 1866.

North, D.C. (1990). Institutions, institutional change and economic performance. Cambridge: Cambridge University Press. . (2005). Understanding the process of economic change. New Jersey: Princeton University Press.

North, D. C., Wallis, J. J. and Weingast, B. R. 2009. Violence and social orders. Cambridge: Cambridge University Press. 
Page, B.D. (2002). 'An unholy alliance': Irish-americans and the political construction of whiteness in Memphis, Tennessee, 1866-1879. Left History, 8(1), 77-96.

Runkle, B.P. (1866). Report of Benjamin P. Runkle, Freedmen’s Bureau Archives, May 23, 1866.

Ryan, J.G. (1977). The Memphis Riot of 1866: terror in a black community during Reconstruction. Journal of Negro History, 62(3), 243-257.

Trefousse, H.L., ed. (1970). Background for radical reconstruction: testimony taken from the hearings of the joint committee on reconstruction, the select committee on the Memphis Riots and massacres, and the select committee on the New Orleans Riots-1866 and 1867. Boston: Little, Brown and Company.

U.S. House of Representatives. 1866. Memphis Riots and Massacres, US House of Representatives, $39^{\text {th }}$ Congress, $1^{\text {st }}$ Session, Report No. 101, Reprinted 1969. Miami: Mnemosyne Publishing Co.

.(1867). New Orleans Riots, US House of Representatives, $39^{\text {th }}$ Congress, $2^{\text {nd }}$ Session, Report No. 16,” Reprinted 1969. New York: Arno Press and the New York Times.

U.S. Senate. (1903). Federal aid in domestic disturbances, $1787-1903.57^{\text {th }}$ Congress, $2^{\text {nd }}$ Session, No. 209. Washington DC: Government Printing Office.

Vandal, G. (1983). The New Orleans Riot of 1866: anatomy of a tragedy. LA: Center for Louisiana Studies.

Walker, B. (1998). 'This is the white man's day': The Irish, white racial identity, and the 1866 Memphis Riots. Left History, 5(2), 31-55.

Waller, A.L. (1984). Community, class, and race in the Memphis Riot of 1866. Journal Of Social History, 18(2), 233-246.

Worley, M. (2004). Reconsidering the role of the Irish in the Memphis Race Riot of 1866. Rhodes Journal of Regional Studies, 1, 38-59. 